\title{
Htumanities $\mathbb{P}_{\text {ress }}$
}

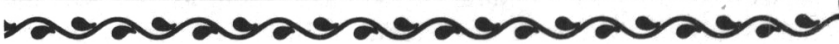

$\mathbb{R}$ oyal $\mathbb{H}$ istorical Society; $A$ nmual $\mathbb{B}$ ibliography of $\mathbb{B}$ ritish and Irish History

G.R. Elton, editor

An extensive bibliography of books and articles published in 1982, dealing with almost all aspects of British and Irish culture and history, ancient to modern.

1983, 203 pp., author \& subject index

ISBN 0-391-02942-8

cloth $\$ 37.50$

An Account of the Mutiny on $\mathbb{H} M$ MS Bounty

Lieutenant William Bligh

Edited with an introduction by Robert Bowman A reprint of Bligh's own narrative account of the famous mutiny, which he published in 1790 in an effort to vindicate himself from charges of having mistreated his crew. A fascinating, well-told tale. 1981, 158 pp., index, illus.

ISBN 0-391-02095-1 cloth $\$ 23.50$ ISBN 0-86299-005-X paper $\$ 10.50$

Rural Rides of the British Churchgoer Joseph Leech

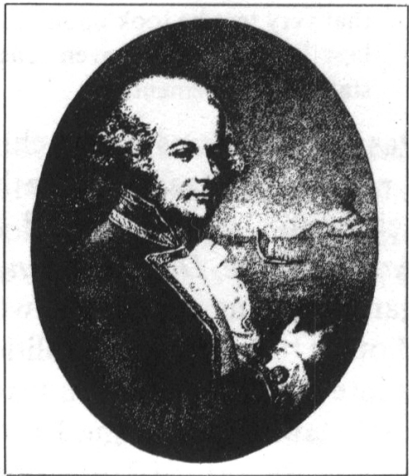

In 1843 the first Churchgoer articles appeared on the back page of the Bristol Times and within a few weeks became a major talking point in Bristol. The first series dealt with the churches of Bristol city but, in 1844, the anonymous Churchgoer began the Rural Rides on his trusty cob "John Bunyan," ready to report on the shortcomings of any parish, church, congregation and sermon in the Bristol area. These comments and descriptions of the rural parishes are now of interest to social historians and to the general reader interested in Bristol and its environs 140 years ago. This book is beautifully produced and copiously illustrated, including a fold-out map of the region. 1982,326 pp., index ISBN 0-904387-50-X ISBN 0-904387-68-2

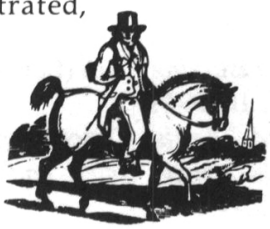

171 First A venue, Atlantic Highlainds, Nod.07716 


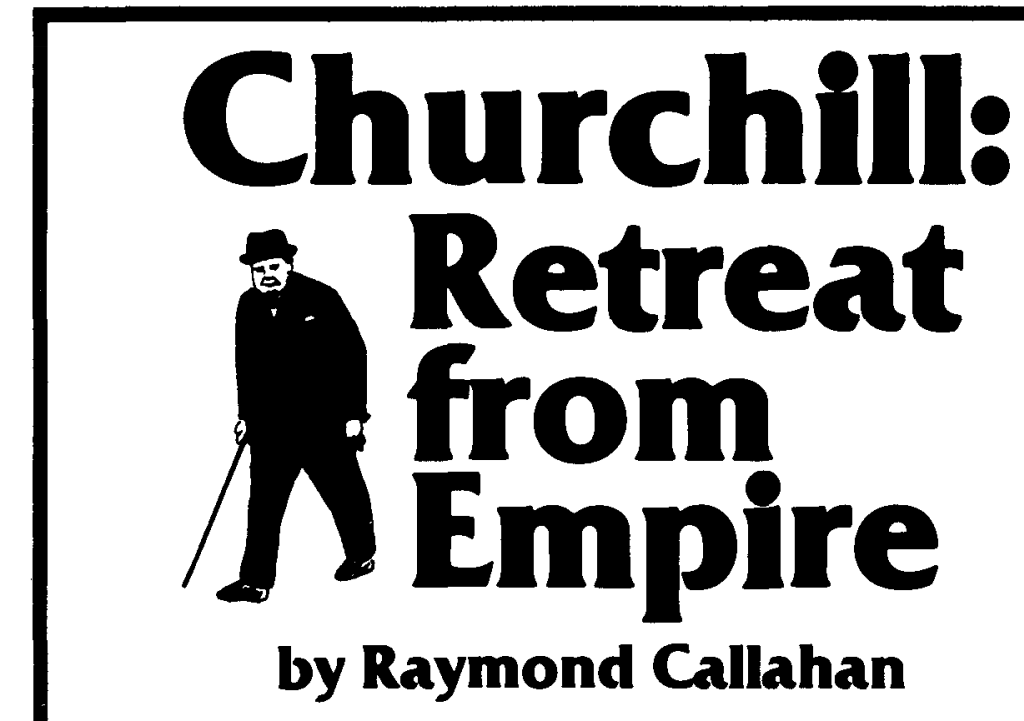

Churchill's fondest goal, "to see the British Empire preserved for a few more generations in its strength and splendor," was defeated through his own heroic determination to "defend our island, whatever the cost may be." In this new book, Callahan examines the significance and ironies of Churchill's political leadership during and after the Second World War, synthesizing with trenchant brevity the many important primary and secondary sources now available on this complex man.

"There is so much written by and about Churchill that it is immensely useful to have this concise account and analysis of his long career. It is hard to imagine a better brief presentation of one of the greatest figures of this century." - Peter Stansky, Stanford University

"This most welcome book provides a sympathetic yet clear-eyed portrait of Churchill as war leader and an enlightening tour through the thickets of wartime controversy. Of particular note is Callahan's placing of Churchill's writings within the context of WW II historiography. Nowhere is the power of Churchill's work more persuasively documented." - Theordore A. Wilson, University of Kansas

Cloth, 256 pp. / Available / $\$ 22.00$

SCHOLARIY RESOURCES INC.

104 Greenhill Avenue

Wilmington, Delaware 19805 


\section{CAMBRIDGE}

That Noble Science of Politics

A Study in Nineteenth-Century Intellectual History

STEFAN COLLINI, DONALD WINCH, and JOHN BURROW

Three eminent historians reassess the way in which Victorians conceived of the "science of politics" by reinterpreting the thought of a wide range of influential Victorians including Ricardo, Marshall, Macaulay, James and John Stuart Mill, Bagehot, Maine, Sidgwick, and Wallas.

"The authors begin by telling us how intellectual history should be done, which is salutary; but their real tour de force comes in showing us how it should be done." - London Review of Books Cloth $\$ 49.50$ Paper $\$ 14.95$

\section{John Ruskin's Labour}

A Study of Ruskin's Social Theory

P.D. ANTHONY

Peter Anthony places Ruskin's penetrating criticism of the values of Victorian England in the context of those of other social critics of the time, notably William Morris and Karl Marx, arguing that the strength of Ruskin's attack paradoxically lay in its detachment from contemporary values. $\quad \$ 37.50$

\section{Rebellion, Popular Protest, and the Social} Order in Early Modern England

\section{PAUL SLACK, Editor}

Originally published in the journal Past and Present, these essays show how the various forms of popular protest in England from the sixteenth to the eighteenth century have been reinterpreted by contemporary scholars. The topics covered range from the great Tudor rebellions of 1536 and 1549 to the urban disorders in London and the food riots of the 1700s.

$\$ 39.50$

\section{Let Your Words Be Few}

Symbolism of Speaking and Silence among Seventeenth-Century Quakers RICHARD BAUMAN

This book offers a fresh and striking insight into the history of the early Quakers of seventeenth-century England through a study of their distinctive ways of speaking and using silence.

Cloth $\$ 32.50$ Paper $\$ 9.95$

\section{Cambridge Commemorated}

\section{An Anthology of University Life}

\section{Compiled by LAURENCE and HELEN FOWLER}

Published in Cambridge University Press' 400th Anniversary year, this illustrated anthology collects passages of prose and poetry about life at the University of Cambridge from its founding to the present day, illuminating by direct quotation from first-hand sources the history and development of a unique institution.

$\$ 27.50$

Cambridge University Press 32 East 57th Street, New York, N.Y. 10022 


\section{R U T G E R S $\#$ BOOK S}

\section{RECENT VIEWS ON BRITISH HISTORY Richard Schlatter, editor}

This book contains original essays by thirteen prominent American historians evaluating books and articles on British and commonwealth history published in the last two decades. The contributors to the volume are Stephen B. Baxter, L.P. Curtis, Jr., Barbara

A. Hanawait, Maurice Lee, Jr., Bryce Lyon, Wallace MacCaffrey, D.C. Moore, Robert A. Smith, Henry L. Snyder, Peter Stansky, David Underdown, Henry R. Winkler, and Robin W. Winks.

\section{0 pages, $\$ 50.00$ cloth \\ EAST LYNNE \\ Mrs. Henry Wood \\ Sally Mitchell, editor}

One of the most popular novels ever written, East Lynne is again available, with a critical introduction by Sally Mitchell. An essential novel for anyone interested in the reading of the typical Victorian women. A run-away best-seller in the $1860 \mathrm{~s} . .$. East lynne runs the gamut of emotions, permitting the reader to indulge in a delicious array of thrills and tears. Martha Vicinus. It is a gripping, psychologically acute presentation of dilemmas that are still with us. Nina Auerbach

500 pages, $\$ 30.00$ cloth, $\$ 9.95$ paper

\section{VICTORIAN EDUCATION AND THE IDEAL OF WOMANHOOD Joan Burstyn}

Burstyn explains why the movement in Britain for higher education for women challenged the Victorian belief in separate spheres for men and women and threatened to destroy the ideal of womanhood. Higher education for women was accepted by the end of the nineteenth century because many families found the ideal unattainable, especially those with daughters who wanted work comparable to their social status. Describes women's struggle to enter the forbidden gate of higher education at a time when they were idealized as domestic priestesses of home, husband, and children. Harvard Educational Review

185 pages, $\$ 12.00$ paper

\section{A BUSY DAY Fanny Burney \\ Tara Ghoshal Wallace, editor}

This edition of Fanny Burney's comedy of young love across social classes (the high and stuffy and the low and vulgar) makes the play available to readers for the first time. Worthy of being read and acted today along with such eighteenth-century favorites as

Sheridan ... and Goldsmith. Michael Adelstein of interest not only to theater historians, but also to those concerned with Burney, with eighteenth-century fiction, with women's studies, and with social history. Susan Staves

225 pages, $\$ 30.00$ cloth, $\$ 10.00$ paper

Rutgers University Press, 30 College Avenue, New Brunswick, NJ 08903

\section{R U T G E R S \#PRE S S}




\section{The Governance of Anglo-Saxon England, 500-1087}

H. R. Loyn. This is the first book in The Governance of England SERIES - a three-volume synthesis of recent research on English medieval government from the Anglo-Saxon period to the triumph of the House of York in 1461 . Providing the considered perspectives of three leading historians of the period, the series is under the general editorship of A. L. Brown. Part I of Professor Loyn's book shows how the idea of belonging to a territorial community that was part of England came to replace the more primitive notions of tribal society. Part II deals with the true "making of England" in the Ioth and I th centuries. Part III sums up the immediate consequences of the Norman Conquest on the principal governmental structures of England. About $\$ 25.00$

\section{Clarendon and the English Revolution}

R. W. Harris. Set against the background of some of the most dramatic and important years in English history, this is the first full biography in nearly 150 years of Edward Hyde, Earl of Clarendon (I 609-1674), the greatest Royalist and statesman of the $\mathrm{I} 7 \mathrm{th}$ century and the first of the great English historians. As a trusted minister, Clarendon did all he could to save Charles I from execution, and to him the Stuarts largely owed their restoration. As a writer and historian, Clarendon occupies a high place in English literature, and his History of the Rebellion remains an enduring classic. This new account of Clarendon's life and thought does full justice to a man of warmth and character who, in the words of Hugh Trevor-Roper, "turned the course of history and made his philosophy come true." About $\$ 39.50$

\section{Stanford University Press}




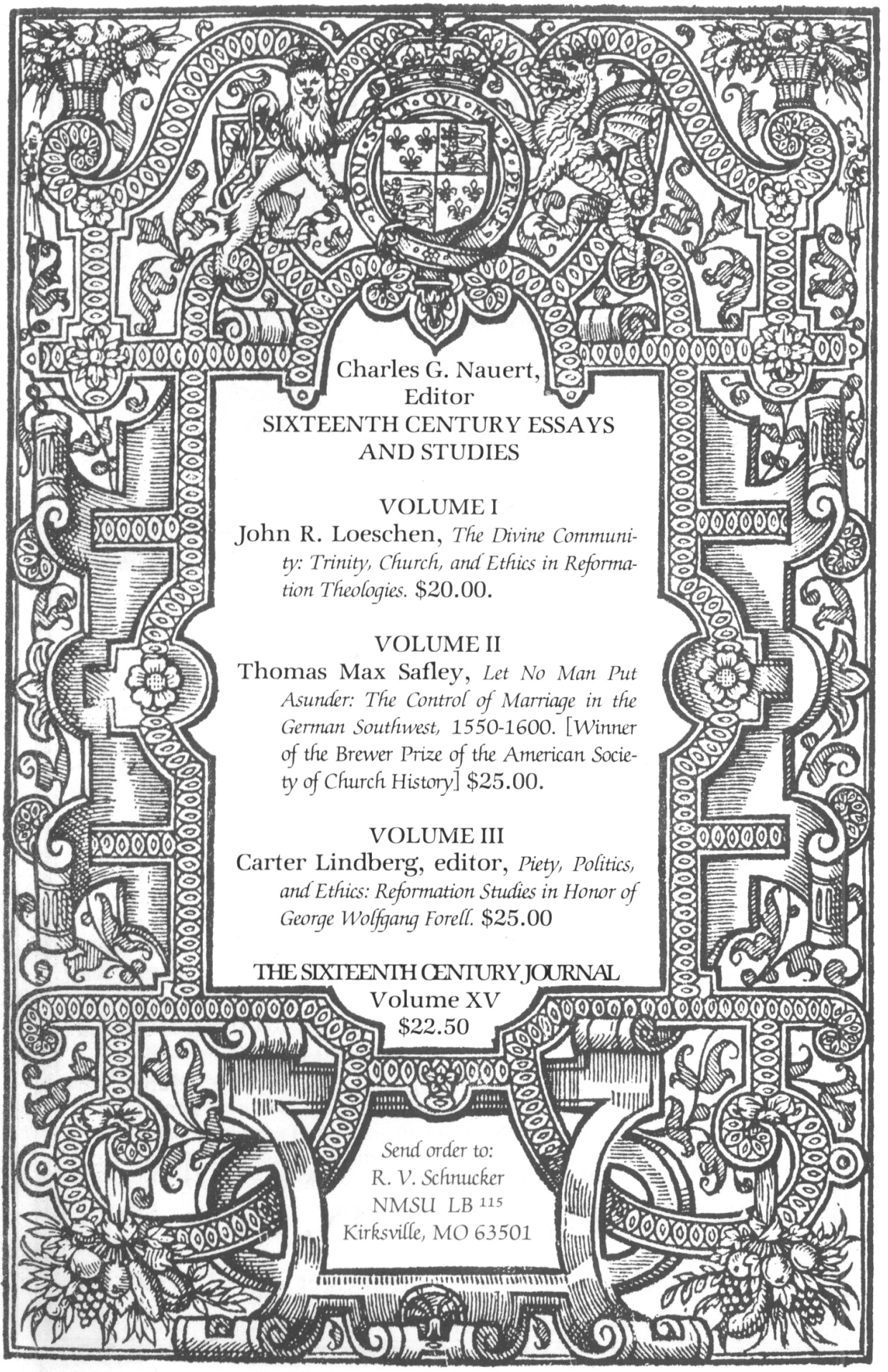




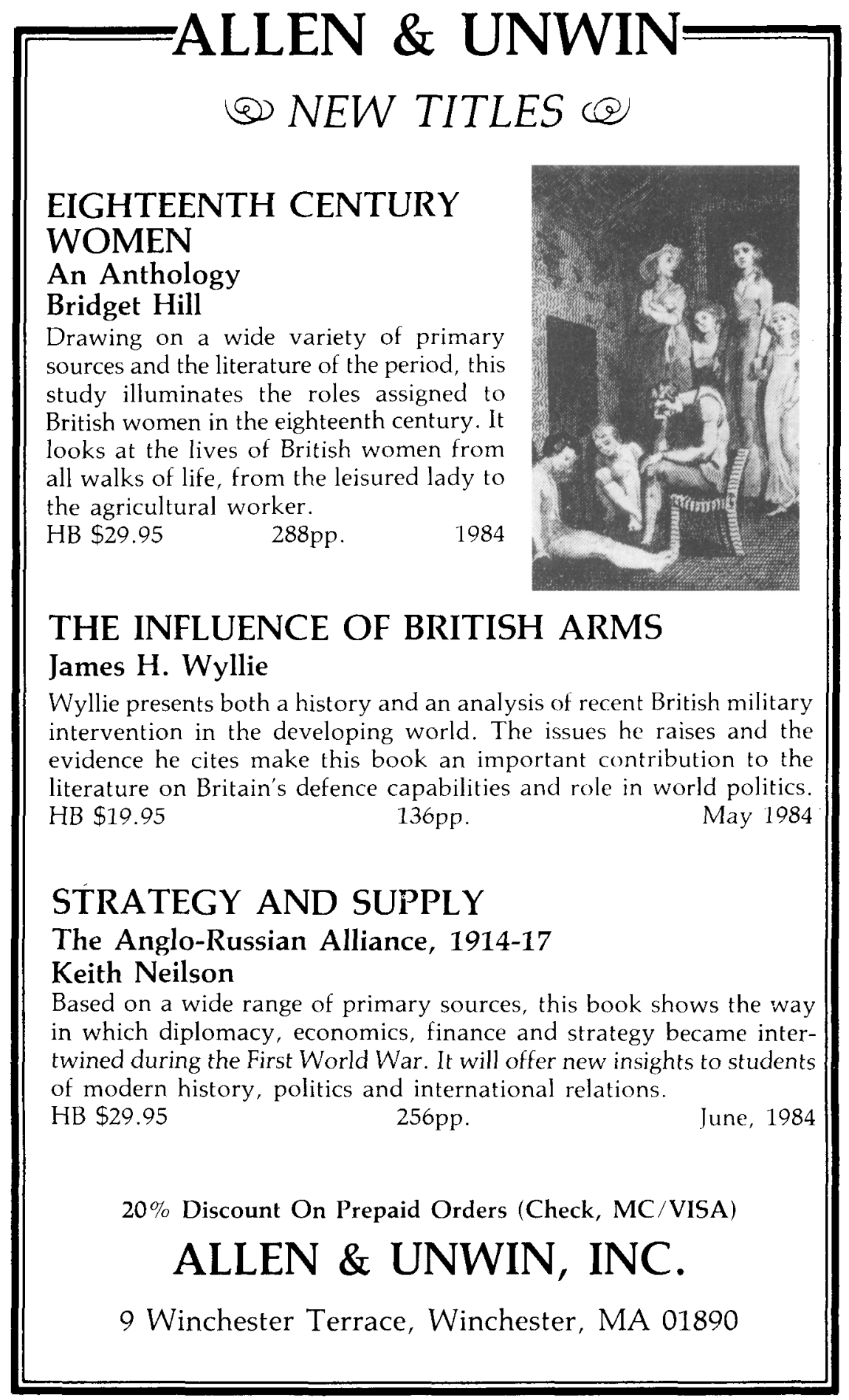




\section{\$manchester}

The Coaching Life

Harry Hanson

In its brief heyday, the British coaching network employed an army of people, and many more depended on it. This entertaining and scholarly book examines the reality and the romance of this inefficient, yet stylish, mode of travel.

$208 \mathrm{pp}$, illustrated

$\$ 20.00$

January 1984

\section{The Impeachment of Michael de la Pole,}

Earl of Suffolk, in 1386

J.S. Roskell

In 1386, the Commons impeached young king Richard II's Chancellor, Michael de la Pole, for dereliction of duty and malversation. This is the first detailed scrutiny of the contemporary significance and future implications of the impeachment.

$216 \mathrm{pp}$

$\$ 27.50$

February 1984

\section{The Historian and the Business of Insurance \\ Oliver $M$. Westall, editor}

Insurance records have recently come to be seen as a unique route by which many of the questions of early industrial and commercial history can be approached. The studies in this volume establish the significance of insurance history and place it in the wider context of economic history. $288 \mathrm{pp}$

$\$ 27.50$

May 1984

\section{The Crawford Papers}

The Journals of David Lindsay, 27th Earl of Crawford, 1892-1940 John l'incent, edilor

These diaries of a Tory Chief Whip and Minister who was also a sensitive and brilliant personality provide an unprecedented view of the Conservative party during the turbulent years around the First World War. A great panorama of an age, the diaries give much insight into social conditions and individuals such as William Morris, Gladstone, and Churchill.

$576 \mathrm{pp} \quad \$ 50.00$

June 1984

\section{Wellington's Legacy}

The Reform of the British Army 1830-54

Hew Strachan

It has long been held that the disaster of the Crimean War resulted from the incompetence of the British army administration. Hew Strachan reexamines this thesis, discussing the military's attempts to reform and the obstacle it faced in the person of the Duke of Wellington.

$420 \mathrm{pp}$

$\$ 40.00$

June 1984

Manchester University Press

51 Washington Street, Dover, New Hampshire 03820

Call toll-free 1-800-343-9444 for MasterCard and Visa Orders. 